Article

\title{
Alpha-Glucosidase Inhibitory Diterpenes from Euphorbia antiquorum Growing in Vietnam
}

\author{
Cong-Luan Tran ${ }^{1}$, Thi-Bich-Ngoc Dao ${ }^{2}$, Thanh-Nha Tran ${ }^{2}$, Dinh-Tri Mai ${ }^{3,4}$, Thi-Minh-Dinh Tran ${ }^{5}$, \\ Nguyen-Minh-An Tran ${ }^{6}{ }^{\circ}$, Van-Son Dang ${ }^{3,7}{ }^{\circledR}$, Thi-Xuyen Vo ${ }^{8}$, Thuc-Huy Duong ${ }^{2, *}$ and Jirapast Sichaem ${ }^{9, *}$
}

\section{check for} updates

Citation: Tran, C.-L.; Dao, T.-B.-N.; Tran, T.-N.; Mai, D.-T.; Tran, T.-M.-D.; Tran, N.-M.-A.; Dang, V.-S.; Vo, T.-X.; Duong, T.-H.; Sichaem, J.

Alpha-Glucosidase Inhibitory

Diterpenes from Euphorbia antiquorum Growing in Vietnam. Molecules 2021, 26, 2257. https://doi.org/10.3390/ molecules 26082257

Academic Editor: Valeria Patricia Sülsen

Received: 29 March 2021

Accepted: 11 April 2021

Published: 13 April 2021

Publisher's Note: MDPI stays neutral with regard to jurisdictional claims in published maps and institutional affiliations.

Copyright: (c) 2021 by the authors. Licensee MDPI, Basel, Switzerland. This article is an open access article distributed under the terms and conditions of the Creative Commons Attribution (CC BY) license (https:// creativecommons.org/licenses/by/ $4.0 /)$.
1 Faculty of Pharmacy and Nursery, Tay Do University, Can Tho 94000, Vietnam; tcluan@tdu.edu.vn

2 Department of Chemistry, University of Education, 280 An Duong Vuong Street, District 5, Ho Chi Minh City 72711, Vietnam; ngocdaosph@gmail.com (T.-B.-N.D.); thanhnhaksb@gmail.com (T.-N.T.)

3 Vietnam Academy of Science and Technology, Graduate University of Science and Technology, 18 Hoang Quoc Viet, Cau Giay, Ha Noi 11355, Vietnam; maidinhtri@gmail.com (D.-T.M.); dvsonitb@gmail.com (V.-S.D.)

4 Institute of Chemical Technology, Vietnam Academy of Science and Technology, 01 Mac Dinh Chi, Ho Chi Minh City 71007, Vietnam

5 Department of Biology, University of Education, 280 An Duong Vuong Street, District 5 , Ho Chi Minh City 72711, Vietnam; dinhttm@hcmue.edu.vn

6 Faculty of Chemical Engineering, Industrial University of Ho Chi Minh City, Ho Chi Minh City 71420, Vietnam; trannguyenminhan@iuh.edu.vn

7 Vietnam Academy of Science and Technology, Institute of Tropical Biology, Ho Chi Minh City 71308, Vietnam

8 Faculty of Technology, Van Lang University, Ho Chi Minh City 71013, Vietnam; xuyen.vt@vlu.edu.vn

9 Research Unit in Natural Products Chemistry and Bioactivities, Faculty of Science and Technology, Thammasat University Lampang Center, Lampang 52190, Thailand

* Correspondence: huydt@hcmue.edu.vn (T.-H.D.); jirapast@tu.ac.th (J.S.); Tel.: +84-919011884 (T.-H.D.); +66-5423-7986 (J.S.)

Abstract: Bioactive-guided phytochemical investigation of Euphorbia antiquorum L. growing in Vietnam led to the isolation of five ent-atisanes, one seco-ent-atisane, and one lathyrane (ingol-type). The structures were elucidated as ent- $1 \alpha, 3 \alpha, 16 \beta, 17$-tetrahydroxyatisane (1), ethyl ent-3,4-seco-4,16 $\beta, 17$ trihydroxyatisane-3-carboxylate (2), ent-atisane-3-oxo-16 $\beta, 17$-acetonide (3), ent-3 $\alpha$-acetoxy-16 $\beta, 17$ dihydroxyatisane (4), ent-16 $\beta, 17$-dihydroxyatisane-3-one (5), calliterpenone (6), and ingol 12-acetate (7). Their chemical structures were unambiguously determined by analysis of one-dimensional (1D) and two-dimensional (2D) nuclear magnetic resonance (NMR) and high resolution mass spectrometry, as well as by comparison with literature data. Among them, $\mathbf{1}$ is a new compound while $\mathbf{2}$ is an ethylated artifact of ent-3,4-seco-4,16 $\beta, 17$-trihydroxyatisane-3-carboxylic acid, a new compound. Isolates were evaluated for alpha-glucosidase inhibition. Compound 3 showed the most significant inhibitory activity against alpha-glucosidase with an $\mathrm{IC}_{50}$ value of $69.62 \mu \mathrm{M}$. Further study on mechanism underlying yeast alpha-glucosidase inhibition indicated that 3 could retard the enzyme function by noncompetitive.

Keywords: Euphorbiaceae; Euphorbia antiquorum L.; ent-atisane; diterpenoid; alpha-glucosidase inhibition

\section{Introduction}

Euphorbia antiquorum L., a medicinal plant, has traditionally been used for various treatments, for example, the latex has been used for emetic, purgative, and diuretic treatments, and the fresh stems for treatment of skin sores, scabies, and toothache [1-3]. Previous chemical studies on E. antiquorum in Thailand, Vietnam, and China have reported the wealth of diterpenoids, including lathyane, ent-atisane, ent-abietane, and ent-kaurane types [3-8]. Those isolated compounds showed various biological activities including cytotoxic, antiinflammatory, anti-HIV activities, and the inhibition of nitric oxide (NO) production [9]. As 
a continuation of our discovery of alpha-glucosidase inhibitory metabolites from E. antiquorum [10], the further investigation on the Vietnamese plant E. antiquorum L. was performed. In this paper, the isolation and structural elucidation of seven diterpenoids, ent- $1 \alpha, 3 \alpha, 16 \beta, 17$ tetrahydroxyatisane (1), ethyl ent-3,4-seco-4,16 $\beta, 17$-trihydroxyatisane-3-carboxylate (2), entatisane-3-oxo-16 $\beta, 17$-acetonide (3) [11], ent-3 $\alpha$-acetoxy-16 $\beta$,17-dihydroxyatisane (4) [12], ent-16 $\beta$,17-dihydroxyatisane-3-one (5) [13], calliterpenone (6) [14], and ingol 12-acetate (7) [15] (Figure 1) from the most bioactive fraction of the title plant are reported. Their structures were elucidated by spectroscopic data analysis and compared with literature data. Isolates were assayed for their alpha-glucosidase inhibition.

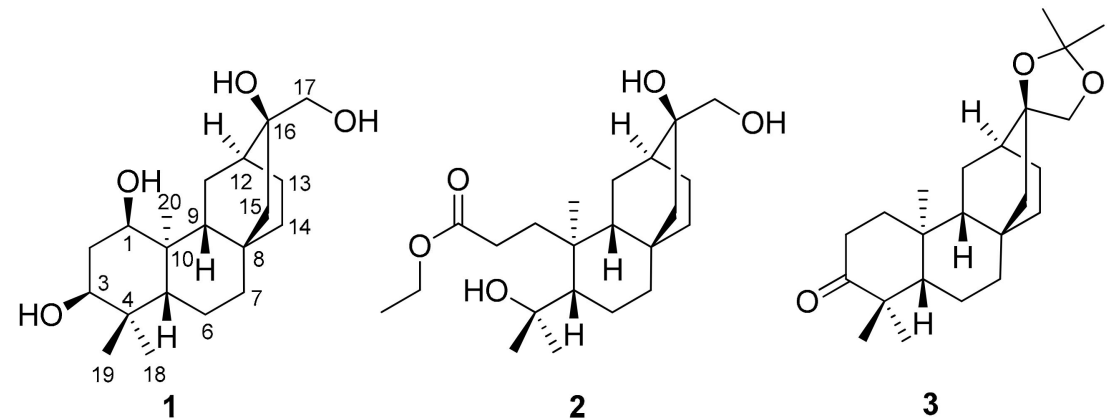<smiles>[R][R](=O)C([R])[R]</smiles>

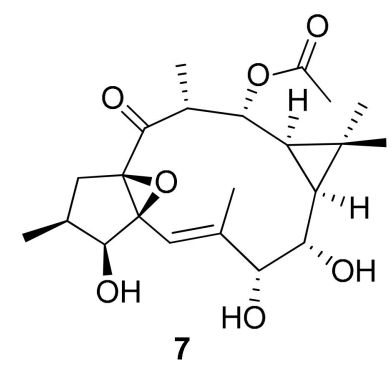

Figure 1. Chemical structures of 1-7.

\section{Results and Discussion}

\subsection{Phytochemical Identification}

Compound 1 was obtained as a colorless gum. Its molecular formula was deuced as $\mathrm{C}_{20} \mathrm{H}_{34} \mathrm{O}_{4}$ by the sodiated ion $[\mathrm{M}+\mathrm{Na}]^{+}$at $m / z 361.2336$ (calculated for 361.2355) in high resolution electrospray ionization mass spectroscopy (HRESIMS) spectrum. The ${ }^{1} \mathrm{H}-\mathrm{NMR}$ spectrum showed the three singlet methyl groups $\left(\delta_{\mathrm{H}} 0.85,0.97\right.$, and 1.00), two oxymethine protons $\left(\delta_{\mathrm{H}} 3.41, \mathrm{t},{ }^{3} J_{\mathrm{H}-\mathrm{H}}=3.2 \mathrm{~Hz}\right.$ and $\left.3.52, \mathrm{t},{ }^{3} J_{\mathrm{H}-\mathrm{H}}=3.2 \mathrm{~Hz}\right)$, one oxymethylene proton $\left(\delta_{\mathrm{H}} 3.34, \mathrm{~d},{ }^{2} J_{\mathrm{H}-\mathrm{H}}=11.2 \mathrm{~Hz}\right.$ and $\left.3.48, \mathrm{~d},{ }^{2} J_{\mathrm{H}-\mathrm{H}}=11.6 \mathrm{~Hz}\right)$. The ${ }^{13} \mathrm{C}$ NMR spectrum, in conjunction with the heteronuclear single quantum coherence (HSQC) spectrum exhibited the resonances of 20 carbon atoms including five methine carbons $\left(\delta_{C} 33.1,44.0,44.5,73.6\right.$, and 78.8 , two latter oxygenated), eight methylene carbons $\left(\delta_{C}\right.$ $19.4,23.3,24.5,28.6,30.3,40.5,54.1$, and 69.7$)$, three methyl carbons $\left(\delta_{C} 15.1,22.3\right.$, and $29.1)$, and four quaternary carbons $\left(\delta_{C} 34.0,38.8,42.8\right.$, and 75.2$)$. The above characteristic data suggested that 1 had an ent-atisane scaffold $[3,10,16]$, further supported by the key heteronuclear multiple bond correlation (HMBC) correlations (Figure 2 and Supplementary Materials Figure S1). Detailed comparison of nuclear magnetic resonance (NMR) data of 1, ent-1 $\beta, 3 \beta, 16 \beta, 17$-tetrahydroxyatisane and ent-1 $\beta, 3 \alpha, 16 \beta, 17$-tetrahydroxyatisane [16] indicated that they shared the same planar structure. Indeed, the presence of the hydroxyl groups at C-1 and C-3 were defined by HMBC correlations of both H-18 $(0.85, \mathrm{~s})$ and $\mathrm{H}-19(0.97, \mathrm{~s})$ to $\mathrm{C}-3\left(\delta_{\mathrm{C}} 78.8\right), \mathrm{C}-4\left(\delta_{\mathrm{C}} 38.8\right)$, and $\mathrm{C}-5\left(\delta_{\mathrm{C}} 44.5\right)$ and of H-20 $(1.00, \mathrm{~s})$ to C-1 $\left(\delta_{C} 73.6\right), C-5, C-9\left(\delta_{C} 44.0\right)$, and C-10 $\left(\delta_{C} 42.8\right)$. The marked differences between 1 and previously mentioned compounds were the configurations of $C-1$ and $C-3$. Particularly, the 
equatorial orientation of $\mathrm{H}-1$ and $\mathrm{H}-3$ were deduced from their small coupling constants: $J_{\mathrm{H}-1 / \mathrm{H}-2 \mathrm{a}} 2.0 \mathrm{~Hz}$ and $J_{\mathrm{H}-3 / \mathrm{H}-2 \mathrm{a}} 3.2 \mathrm{~Hz}$. This finding was further strengthened by nuclear overhauser effect spectroscopy (NOESY) correlations. Indeed, NOESY correlations of $\mathrm{H}-1 / \mathrm{H}-2 \mathrm{a}, \mathrm{H}-3 / \mathrm{H}-2 \mathrm{a}, \mathrm{H}-2 \mathrm{a} / \mathrm{H}-20, \mathrm{H}-20 / \mathrm{H}-13$, and H-20/H-14 indicated the co-facial of all mentioned protons. The orientation of $16-\mathrm{OH}$ was validated by NOESY correlations of H-17/H-9 and H-9/H-5 (Figure 3 and Supplementary Materials Figure S2), supported by the NMR comparison of the previously reported ent-atisanes, isolated from the same bio-source [3,10]. Altogether, the chemical structure of $\mathbf{1}$ was established as shown, namely ent-1 $\alpha, 3 \alpha, 16 \beta, 17$-tetrahydroxyatisane.

Compound 2 might be an artifact of ent-3,4-seco-4,16 $\beta, 17$-trihydroxyatisane-3-carboxylic acid when using ethyl acetate during the extraction. It is worth noting that the mother compounds of 2 could be either methyl ent-3,4-seco-4,16 $\beta, 17$-trihydroxyatisane-3-carboxylate or ent-3,4-seco-4,16 $\beta, 17$-trihydroxyatisane-3-carboxylic acid which were new compounds. The occurrence of 2 proposed that ent-3,4-seco-4,16 $\beta, 17$-trihydroxyatisane-3-carboxylic acid or methyl ent-3,4-seco-4,16 $\beta, 17$-trihydroxyatisane-3-carboxylate were original compounds of the plant E. antiquorum growing in Vietnam. Up to now, very few ent-3,4-seco-atisanes have been reported in E. antiquorum [11]. Therefore, biologically active new chemical components from this plant might yet be found.

Compounds 1-4, 6, and 7 were evaluated for their alpha-glucosidase inhibition (Table 1). All tested compounds showed stronger activity than the positive control, acarbose $\left(\mathrm{IC}_{50} 332.5 \mu \mathrm{M}\right)$, similar to previously reported ent-atisane [10]. Among them, compound 3 showed the highest alpha-glucosidase inhibition $\left(\mathrm{IC}_{50} 69.62 \mu \mathrm{M}\right)$, indicating the important role of the acetonide moiety at C-16 and C-17. Compound 3 was prepared rapidly when 5 reacted with acetone under acidic catalyst at room temperature in one day. This indicated that $\mathbf{3}$ was an artifact of $\mathbf{5}$ when using acetone during the isolation.

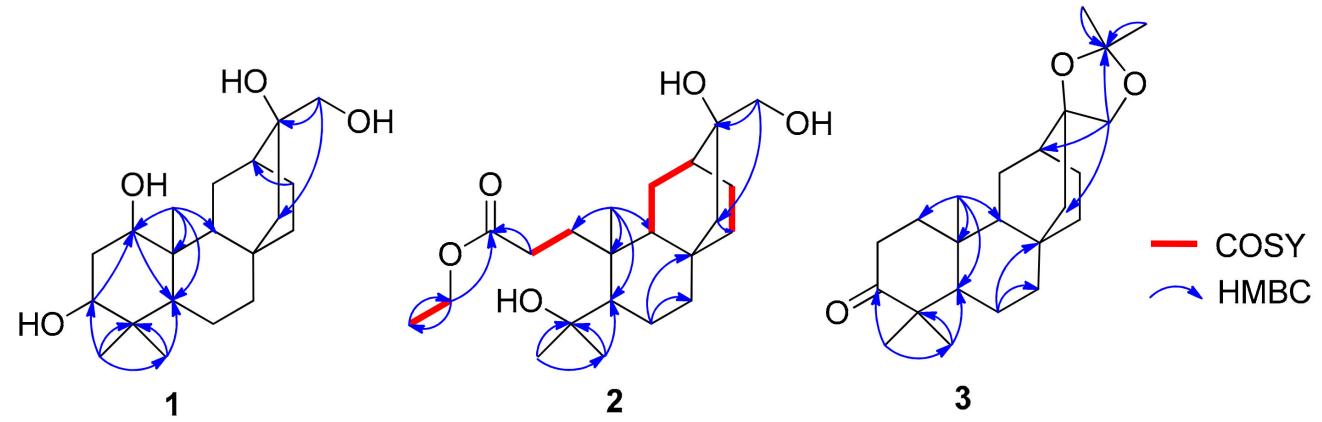

Figure 2. Key COSY and HMBC correlations of 1-3.

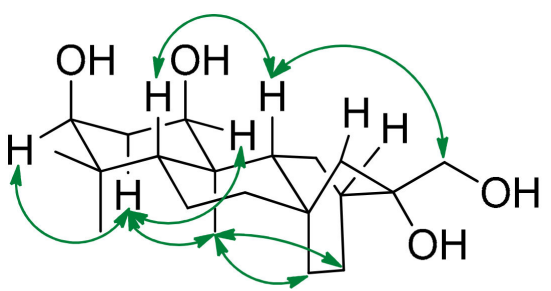

1

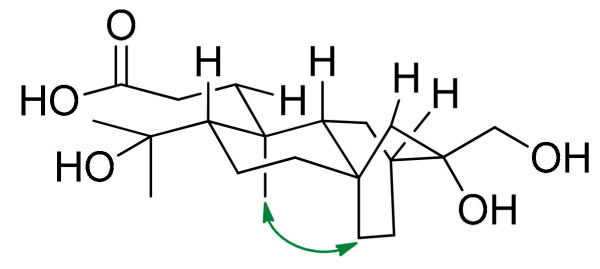

2

Figure 3. Key NOESY correlations of $\mathbf{1}$ and 2.

\subsection{Alpha-Glucosidase Inhibitory Activity of Isolated Compounds}

The in vitro alpha-glucosidase inhibitory activity of $\mathbf{1 - 4 , 6}$, and $\mathbf{7}$ was evaluated. All compounds displayed significant alpha-glucosidase inhibitory activity with $\mathrm{IC}_{50}$ values in the range of $69.62-156.14 \mu \mathrm{M}$. The inhibition of isolated compounds on other glycosidases should be evaluated to determine the selectivity. Unfortunately, these tests were not performed due to the minute amounts of isolated compounds. 
Table 1. Alpha-glucosidase inhibitory activity of 1-4, 6, and 7.

\begin{tabular}{cc}
\hline Compound & $\mathrm{IC}_{\mathbf{5 0}}(\boldsymbol{\mu M})$ \\
\hline $\mathbf{1}$ & 125.20 \\
$\mathbf{2}$ & 130.80 \\
$\mathbf{3}$ & 69.62 \\
$\mathbf{4}$ & 102.18 \\
$\mathbf{6}$ & 156.14 \\
$\mathbf{7}$ & 115.23 \\
Acarbose & 332.5 \\
\hline
\end{tabular}

\subsection{Inhibition Type and Inhibition Constants of $\mathbf{3}$ on Alpha-Glucosidase}

In order to examine the inhibition mechanism of 3 , their activity was measured at the different concentration of 4-nitrophenyl $\beta$-D-glucopyranoside ( $p$ NPG). The LineweaverBurk plots of a kinetic study of 3 (Figure $4 \mathrm{~A}$ ) showed linearity at each concentration examined $(0,13.8,27.7$, and $55.5 \mu \mathrm{M})$, which all intersected the $x$-axis in the second quadrant. The kinetic analysis revealed that $V_{\max }$ decreased while $K_{\mathrm{m}}$ remained constant, which showed that 3 acted as a noncompetitive inhibitor. The inhibition constant $\left(K_{\mathrm{i}}\right)$ was $65.8 \mu \mathrm{M}$ (Figure 4B).

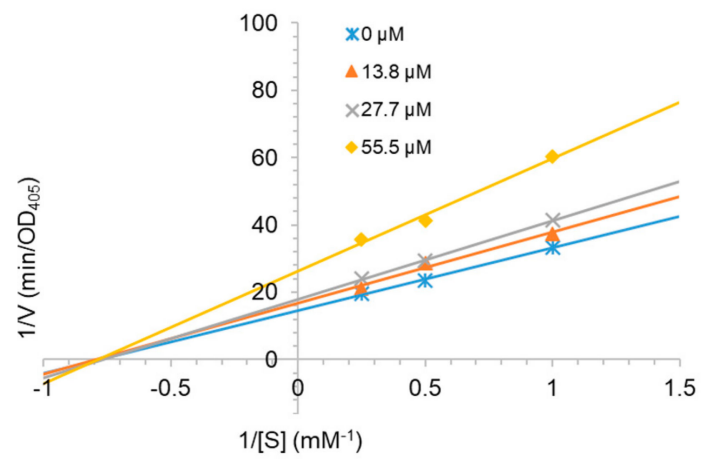

(A)

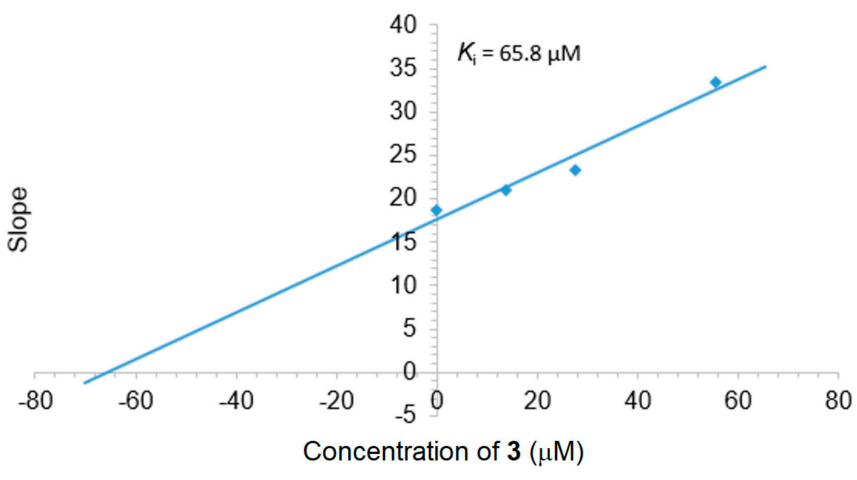

(B)

Figure 4. Lineweaver-Burk plot for alpha-glucosidase inhibition by 3 (A) and the secondary plot of slope vs. the inhibitor concentration $(\mathbf{B})$.

\section{Materials and Methods}

\subsection{Source of the Plant Material}

The aerial parts of E. antiquorum were collected in Binh Thuan province, Vietnam. The scientific name of the plant was determined by Dr. Tran Cong Luan, Faculty of Pharmacy and Nursery, Tay Do University, Can Tho, Vietnam. A voucher specimen of E. antiquorum (No UP B007) was deposited in the herbarium of the Department of Organic Chemistry, Ho Chi Minh City University of Science, National University—HCMC.

\subsection{Isolation}

The air-dried and ground E. antiquorum $(6 \mathrm{~kg})$ was extracted exhaustively with methanol $(10 \mathrm{~L} \times 3)$ at room temperature. After evaporation of the extracts, the residue $(757.2 \mathrm{~g})$ was dissolved in ethanol, suspended in water then successfully partitioned with $n$-hexane, $n$-hexane-EtOAc $(1: 1, v / v)$, and EtOAc to give $n$-hexane, $n$-hexane-EtOAc (1:1, $v / v)$, and EtOAc extracts. The EtOAc extract $(180.7 \mathrm{~g})$ was purified by silica gel column chromatography (CC) using $n$-hexane-EtOAc-Acetone $(1: 1: 2, v / v / v)$ as an eluent, to afford seven major fractions, labelled A-E. Fractions $B$ and $C$ were investigated in our previous reports [10]. Fractions $\mathrm{D}$ were selected for further isolation. The fraction $\mathrm{D}(12.3 \mathrm{~g})$ was loaded onto Sephadex LH-20 CC eluting with the solvent system of $\mathrm{CH}_{2} \mathrm{Cl}_{2}-\mathrm{MeOH}$ (1:3, $v / v)$, yielding six fractions, D1-6. Fraction D3 (1.3 g) was applied to silica gel CC, eluted 
with the solvent system of $n$-hexane-EtOAc $(1: 1.5, v / v)$ to give four subfractions, D3.1-3.4. Subfraction D3.4 (227 mg) was selected for C18 reversed-phase CC using the solvent system of $\mathrm{MeOH}-\mathrm{H}_{2} \mathrm{O}(2: 1, v / v)$ as a mobile phase to obtain $4(3.8 \mathrm{mg})$ and $2(3.2 \mathrm{mg})$. Fraction D4 (1.72 g) was separated by silica gel CC using $n$-hexane-EtOAc-MeOH (2:1:0.1) to give three subfractions, D4.1-D4.3. Subfraction D4.3 (501 mg) was chromatographed by C18 reversedphase $\mathrm{CC}$ with solvent $\mathrm{H}_{2} \mathrm{O}-\mathrm{MeOH}(2: 1)$ to afford two subfractions D4.A-D4.B. Subfraction D4.A (151.6 mg) was further purified by silica gel CC using $n$-hexane-EtOAc-Acetone (4:3:2, $v / v / v)$ as an eluent and $3(3.5 \mathrm{mg})$ were obtained. Subfraction D4.B (249.7 $\mathrm{mg})$ was further purified using the same manner to afford $1(4.0 \mathrm{mg})$ and $6(3.3 \mathrm{mg})$. Fraction D5 (2.1 $\mathrm{g})$ was applied to silica gel CC with solvent system of $n$-hexane-EtOAc-Acetone $(1: 1.5: 1, v / v / v)$ as a mobile phase to yield five subfractions, D5.1-D5.5. Subfraction D5.3 (313.2 mg) was selected for reversed-phase CC, eluted with the solvent system of $\mathrm{MeOH}-\mathrm{H}_{2} \mathrm{O}(2: 1, v / v)$ to give 5 (3.9 $\mathrm{mg})$ and 7 (4.1 $\mathrm{mg})$.

\subsubsection{Ent-1 $\alpha, 3 \alpha, 16 \beta, 17$-tetrahydroxyatisane (1)}

Colorless gum. $[\alpha]^{20} \mathrm{D}+117$ (c 0.1, MeOH). HR-ESI-MS m/z 301.2336 (calcd. for $\left.\mathrm{C}_{20} \mathrm{H}_{34} \mathrm{O}_{4} \mathrm{Na}, 301.2355\right) ;{ }^{1} \mathrm{H}-\mathrm{NMR}\left(\mathrm{CD}_{3} \mathrm{OD}, 400 \mathrm{MHz}\right) \delta_{\mathrm{H}} 3.52(1 \mathrm{H}, \mathrm{t}, J=3.2, \mathrm{H}-1), 3.48(1 \mathrm{H}$, $\mathrm{d}, J=11.6, \mathrm{H}-17 \mathrm{a}), 3.41(1 \mathrm{H}, \mathrm{t}, J=3.2, \mathrm{H}-3), 3.34(1 \mathrm{H}, \mathrm{d}, J=11.2, \mathrm{H}-17 \mathrm{~b}), 2.24(1 \mathrm{H}, \mathrm{dt}, J=15.1$, 2.8, H-2a), 2.07 (1H, m, H-9), 2.04 (1H, m, H-13a), 1.89 (1H, m, H-14a), 1.85 (1H, m, H-2b), $1.81(1 \mathrm{H}, \mathrm{m}, \mathrm{H}-12), 1.67$ (1H, m, H-11a), 1.60 (1H, m, H-5), 1.49 (1H, m, H-11b), 1.47 (2H, m, H-6), 1.43 (1H, m, H-7a), 1.18 (1H, m, H-13b), 1.15 (1H, m, H-7b), 1.12 (2H, s, H- 15), 1.00 (3H, s, H-20), 0.97 (3H, s, H-19), $0.85(3 \mathrm{H}, \mathrm{s}, \mathrm{H}-18), 0.78(1 \mathrm{H}, \mathrm{m}, \mathrm{H}-14 \mathrm{~b}) .{ }^{13} \mathrm{C}-\mathrm{NMR}\left(\mathrm{CD}_{3} \mathrm{OD}\right.$, $100 \mathrm{MHz}) \delta_{\mathrm{C}} 78.8$ (C-3), 75.2 (C-16), 73.6 (C-1), 69.7 (C-17), 54.1 (C-15), 44.5 (C-5), 44.0 (C-9), 42.8 (C-10), 40.5 (C-7), 38.8 (C-4), 34.0 (C-8), 33.1 (C-12), 30.3 (C-2), 29.1 (C-19), 28.6 (C-14), 24.5 (C-11), 23.3 (C-13), 22.3 (C-18), 19.4 (C-6), 15.1 (C-20).

\subsubsection{Ethyl ent-3,4-seco-4,16 $\beta, 17$-trihydroxyatisane-3-carboxylate (2)}

Colorless gum. [ $\alpha]^{20} \mathrm{D}+121$ (c $\left.0.1, \mathrm{MeOH}\right)$. HR-ESI-MS $m / z 405.2628$ (calcd. for $\left.\mathrm{C}_{22} \mathrm{H}_{38} \mathrm{O}_{5} \mathrm{Na}, 405.2617\right) ;{ }^{1} \mathrm{H}-\mathrm{NMR}\left(\mathrm{CD}_{3} \mathrm{OD}, 400 \mathrm{MHz}\right) \delta_{\mathrm{H}} 4.09(2 \mathrm{H}, \mathrm{q}, J=7.2 \mathrm{~Hz}, \mathrm{H}-21)$, $3.49(1 \mathrm{H}, \mathrm{d}, J=11.2 \mathrm{~Hz}, \mathrm{H}-17 \mathrm{a}), 3.35$ (1H, d, J = 11.6 Hz, H-17b), 2.55 (1H, m, H-2a), 2.28 (1H, m, H-2b), 2.18 (1H, m, H-1a), 1.95 (1H, m, H-11a), 1.90 (1H, m, H-14a), 1.84 (1H, m, H-12), 1.65 (2H, m, H-13), 1.56 (1H, m, H-1b), 1.51 (2H, m, H-6), 1.47 (1H, m, H-9), 1.39 (1H, m, H-5), 1.33 (1H, m, H-7a), 1.27 (3H, s, H-18), 1.27 (3H, s, H-19), 1.25 (3H, t, J = 7.2 Hz, H-22), 1.21 (1H, m, H-11b), 1.18 (1H, m, H-15a), $1.14(3 \mathrm{H}, \mathrm{s}, \mathrm{H}-20), 1.11(1 \mathrm{H}, \mathrm{m}, \mathrm{H}-7 \mathrm{~b}), 1.09(1 \mathrm{H}$, m, H-15b), 0.84 (1H, m, H-14b). ${ }^{13} \mathrm{C}-\mathrm{NMR}\left(\mathrm{CD}_{3} \mathrm{OD}, 100 \mathrm{MHz}\right) \delta_{\mathrm{C}} 177.0$ (C-3), $76.1(\mathrm{C}-4)$, 75.0 (C-16), 69.7 (C-17), 61.4 (C-21), 53.5 (C-5), 53.3 (C-15), 45.1 (C-9), 42.3 (C-10), 40.0 (C-7), 35.5 (C-12), 35.1 (C-1), 34.1 (C-8), 32.7 (C-19), 30.1 (C-2), 28.4 (C-18), 27.9 (C-14), 24.2 (C-13), 23.9 (C-11), 23.4 (C-6), 19.0 (C-20), 14.6 (C-22).

\subsection{Alpha-Glucosidase Inhibition Assay}

Saccharomyces cerevisiae $\alpha$-glucosidase (E.C 3.2.1.20), acarbose, and 4-nitrophenyl $\beta$-Dglucopyranoside ( $p$ NPG) were obtained from Sigma-Aldrich Co (Saint Louis, MI, USA). The alpha-glucosidase $(0.2 \mathrm{U} / \mathrm{mL})$ and substrate $(5.0 \mathrm{mM} p \mathrm{NPG})$ were dissolved in $100 \mathrm{mM}$ pH 6.9 sodium phosphate buffer [17]. The inhibitor $(50 \mu \mathrm{L})$ was preincubated with alphaglucosidase at $37^{\circ} \mathrm{C}$ for $20 \mathrm{~min}$, and then the substrate $(40 \mu \mathrm{L})$ was added to the reaction mixture. The enzymatic reaction was carried out at $37{ }^{\circ} \mathrm{C}$ for $20 \mathrm{~min}$ and stopped by adding $0.2 \mathrm{M} \mathrm{Na}_{2} \mathrm{CO}_{3}(130 \mu \mathrm{L})$. Enzymatic activity was quantified by measuring absorbance at $405 \mathrm{~nm}$ (CLARIOstar plus, BMG LABTECH, Ortenberg, Germany). All samples were analyzed in triplicate at five different concentrations around the $\mathrm{IC}_{50}$ values, and the mean values were retained. The inhibition percentage $(\%)$ was calculated by the following equation:

$$
\text { Inhibition }(\%)=\left[1-\left(\mathrm{A}_{\text {sample }} / \mathrm{A}_{\text {control }}\right)\right] \times 100 \text {. }
$$




\subsection{Inhibitory Type Assay of $\mathbf{3}$ on Alpha-Glucosidase}

The mechanisms of inhibition of alpha-glucosidase by 3 were determined by Lineweaver-Burk plots (Microsoft Excel 2010, Redmond, WA, USA), using methods similar to those reported in the literature. Enzyme inhibition due to various concentrations of the 3 were evaluated by monitoring the effects of different concentrations of the substrate. For Lineweaver-Burk double reciprocal plots 1 /enzyme velocity $(1 / \mathrm{V})$ vs. 1 /substrate concentration $(1 /[S])$, the inhibition type was determined using various concentrations of $p$ NPG $(1 \mathrm{mM}, 2 \mathrm{mM}$, and $4 \mathrm{mM})$ as a substrate in the presence of different concentrations of the test compound $(0,13.8,27.7$, and $55.5 \mu \mathrm{M})$. The experiments were carried out in three replicates. The mixtures were incubated at $37{ }^{\circ} \mathrm{C}$ and the optical density was measured at $405 \mathrm{~nm}$ every $1 \mathrm{~min}$ for $30 \mathrm{~min}$ with the Clariostar Labtech microplate reader (Ortenberg, Germany). Optimal concentrations of the tested compound were chosen based on the $\mathrm{IC}_{50}$ value. The inhibition constants were obtained graphically from secondary plots (Microsoft Excel 2010, Redmond, WA, USA).

\subsection{Isolation and Structure Elucidation of the Compounds}

Gravity column chromatography was performed on silica gel $60(0.040-0.063 \mathrm{~mm}$, Merck, Darmstadt, Germany). Thin-layer chromatography (TLC) for checking chromatographic patterns of fractions and isolated compounds was carried out on silica gel $60 \mathrm{~F}_{254}$ (Merck, Darmstadt Germany) and spots were visualized by spraying with $10 \% \mathrm{H}_{2} \mathrm{SO}_{4}$ solution followed by heating. Specific rotations were obtained on a Jasco P-1010 polarimeter (Oklahoma City, OK, USA). The HRESIMS were recorded on a MicroOTOF-Q mass spectrometer (Bruker, MA, USA). The NMR spectra were measured on a Bruker Avance $500 \mathrm{MHz}$ spectrometer (Bruker, MA, USA).

\section{Conclusions}

From the Vietnamese plant E. antiquorum, seven alpha-glucosidase inhibitors were isolated and elucidated, including ent- $1 \alpha, 3 \alpha, 16 \beta, 17$-tetrahydroxyatisane (1), ethyl ent-3,4seco-4,16 $\beta, 17$-trihydroxyatisane-3-carboxylate (2), ent-atisane-3-oxo-16 $\beta, 17$-acetonide (3), ent-3 $\alpha$-acetoxy-16 $\beta, 17$-dihydroxyatisane (4), ent-16 $\beta, 17$-dihydroxyatisane-3-one (5), calliterpenone (6), and ingol 12-acetate (7). To the best of our knowledge, compounds 1-6 were isolated from this species for the first time. Compounds $\mathbf{1}$ and $\mathbf{2}$ were new compounds. Compound 3 exhibited the highest inhibitory activity against yeast alpha-glucosidase inhibitory activity with $\mathrm{IC}_{50}$ value of $69.62 \mu \mathrm{M}$. The kinetic mechanism of 3 indicated that it retarded alpha-glucosidase in a noncompetitive manner. In this study, compound 3 showed the most powerful yeast $\alpha$-glucosidase inhibitory activity. However, it could not be considered a potential antidiabetic until other studies were performed.

Supplementary Materials: The following are available online, Figure S1. Key COSY and HMBC correlations of 1-3. Figure S2. Key NOESY correlations of 1, Figures S3-S9. Spectral characterization of 1, Figures S10-S16. Spectral characterization of 2, Figures S17-S21. Spectral characterization of 3, Table S1. ${ }^{1} \mathrm{H}-\mathrm{NMR}$ data for compounds $\mathbf{1 - 4}$ in $\mathrm{CD}_{3} \mathrm{OD}$, Table S2. ${ }^{13} \mathrm{C}-\mathrm{NMR}$ data for compounds 1-4 in $\mathrm{CD}_{3} \mathrm{OD}$, Table S3. Alpha-glucosidase inhibitory activity of $\mathbf{1 - 4}, \mathbf{6}$, and 7.

Author Contributions: Conceptualization, J.S., T.-B.-N.D., T.-N.T.; methodology, T.-H.D., T.-B.-N.D., T.-N.T., D.-T.M.; software, T.-H.D., V.-S.D., N.-M.-A.T.; formal analysis, C.-L.T., D.-T.M., T.-M.-D.T.; investigation, J.S., T.-H.D., D.-T.M., T.-M.-D.T.; resources, C.-L.T., T.-X.V., T.-H.D.; data curation, T.-B.-N.D., T.-N.T.; writing-original draft preparation, T.-H.D., T.-X.V., D.-T.M.; writing-review and editing, J.S., C.-L.T., V.-S.D.; visualization, T.-H.D., J.S. All authors have read and agreed to the published version of the manuscript.

Funding: This study was supported by Thammasat University Research Unit in Natural Products Chemistry and Bioactivities. This study was supported by Ho Chi Minh University of Education (CS2020.19.23).

Institutional Review Board Statement: Not applicable. 
Informed Consent Statement: Not applicable.

Data Availability Statement: All data supporting this study is available in the manuscript and the Supplementary Materials.

Conflicts of Interest: The authors declare no conflict of interest.

Sample Availability: Samples of the compounds are not available from the authors.

\section{References}

1. Qi, W.-Y.; Zhao, J.-X.; Wei, W.-J.; Gao, K.; Yue, J.-M. Quorumolides A-C, Three Cembranoids from Euphorbia antiquorum. J. Org. Chem. 2018, 83, 1041-1045. [CrossRef] [PubMed]

2. Dong, M.; Chen, X.-Q.; Chen, C.-H.; Li, R.-T. Terpenes from Euphorbia antiquorum and Their in Vitro Anti-HIV Activity. Chem. Biodivers. 2018, 15, e1700560. [CrossRef] [PubMed]

3. Yuan, W.-J.; Gao, W.-F.; Zhao, J.-Y.; Zhang, Y.; Chen, D.-Z.; Li, S.-L.; Di, Y.-T.; Hao, X.-J. Diterpenes with potential treatment of vitiligo from the aerials parts of Euphorbia antiquorum L. Fitoterapia 2020, 144, 104583. [CrossRef] [PubMed]

4. Tran, T.-N.; Sichaem, J.; Nguyen, V.-K.; Nguyen, H.-H.; Cao, T.-T.; Nguyen, T.-P.; Vo, V.-G.; Niamnont, N.; Nguyen, N.-H.; Duong, T.-H. New diterpenoids from the stems of Euphorbia antiquorum growing in Vietnam. Nat. Prod. Res. 2020, 1-8. [CrossRef] [PubMed]

5. An, L.; Liang, Y.; Yang, X.; Wang, H.; Zhang, J.; Tuerhong, M.; Li, D.; Wang, C.; Lee, D.; Xu, J.; et al. NO inhibitory diterpenoids as potential anti-inflammatory agents from Euphorbia antiquorum. Bioorg. Chem. 2019, 92, 103237. [CrossRef] [PubMed]

6. Yin, Z.-Y.; Dai, Y.; Hua, P.; Sun, Z.-J.; Cheng, Y.-F.; Yuan, S.-H.; Chen, Z.-Y.; Gu, Q. Discovery of diverse diterpenoid scaffolds from Euphorbia antiquorum and their activity against RANKL-induced osteoclastogenesis. Bioorg. Chem. 2019, 92, 103292. [CrossRef] [PubMed]

7. Liang, Y.; An, L.; Shi, Z.; Zhang, X.; Xie, C.; Tuerhong, M.; Song, Z.; Ohizumi, Y.; Lee, D.; Shuai, L.; et al. Bioactive Diterpenoids from the Stems of Euphorbia antiquorum. J. Nat. Prod. 2019, 82, 1634-1644. [CrossRef] [PubMed]

8. Choodej, S.; Hanthanong, S.; Aree, T.; Pudhom, K. Diterpenoids from the aerial parts of Euphorbia antiquorum and their efficacy on nitric oxide inhibition. Phytochemistry 2020, 180, 112523. [CrossRef] [PubMed]

9. Shi, Q.-W.; Su, X.-H.; Kiyota, H. Chemical and Pharmacological Research of the Plants in Genus Euphorbia. Chem. Rev. 2008, 108, 4295-4327. [CrossRef] [PubMed]

10. Tran, T.-N.; Sichaem, J.; Nguyen, V.-K.; Chavasiri, W.; Niamnont, N.; Jongaramruong, J.; Duong, T.-H. A new ent-atisane diterpenoid from the aerial parts of Euphorbia antiquorum L. Nat. Prod. Res. 2021, 35, 312-317. [CrossRef] [PubMed]

11. Huang, C.-S.; Luo, S.-H.; Li, Y.-L.; Li, C.-H.; Hua, J.; Liu, Y.; Jing, S.-X.; Wang, Y.; Yang, M.-J.; Li, S.-H. Antifeedant and Antiviral Diterpenoids from the Fresh Roots of Euphorbia jolkinii. Nat. Prod. Bioprospect. 2014, 4, 91-100. [CrossRef] [PubMed]

12. Yill, D.; Yuting, L. Carbon-13 NMR spectral studies of some atisane type diterpene dẻivatives. Bopuxue Zazhi 1992, 9, $277-282$.

13. Lal, A.R.; Cambie, R.C.; Rutledge, P.S.; Woodgate, P.D. Ent-atisane diterpenes from Euphorbia fidjiana. Phytochemistry 1990, 29, 1925-1935. [CrossRef]

14. Shao, Y.; Hu, L.-H.; Sim, K.-Y.; Goh, S.-H. Lignanoids and Diterpenoids from Callicarpa furfuraceae. Helvetica Chim. Acta 2006, 89, 64-72. [CrossRef]

15. Abo, K.A.; Evans, F.J. A Tri-Ester of Ingol from the Latex of Euphorbia kamerunica. J. Nat. Prod. 1982, 45, 365-366. [CrossRef]

16. Wang, M.; Wang, Q.; Wei, Q.; Li, J.; Guo, C.; Yang, B.; Kuang, H. Two new ent-atisanes from the root of Euphorbia fischeriana Steud. Nat. Prod. Res. 2015, 30, 144-149. [CrossRef] [PubMed]

17. Devi, A.P.; Duong, T.-H.; Ferron, S.; Beniddir, M.A.; Dinh, M.-H.; Nguyen, V.-K.; Pham, N.-K.-T.; Mac, D.-H.; Boustie, J.; Chavasiri, W.; et al. Salazinic Acid-Derived Depsidones and Diphenylethers with $\alpha$-Glucosidase Inhibitory Activity from the Lichen Parmotrema dilatatum. Planta Med. 2020, 86, 1216-1224. [CrossRef] [PubMed] 